\title{
INTERACTIONS OF PLANTS WITH NOBLE METAL NANOPARTICLES (review)
}

\section{L.A. DYKMAN, S.Yu. SHCHYOGOLEV}

Institute of Biochemistry and Physiology of Plants and Microorganisms RAS, Federal Agency of Scientific Organizations, 13, prosp. Entuziastov, Saratov, 410049 Russia, e-mail dykman_1@ibppm.ru, shegolev_s@ibppm.ru ORCID: Dykman L.A. orcid.org/0000-0003-2440-6761

The authors declare no conflict of interests

Acknowledgements:

Supported partly by Russian Foundation for Basic Research (projects № 14-04-00114 and № 16-04-00520)

Received June 23, 2016

\section{Abstract}

Gold and silver nanoparticles are used in a variety of biomedical practice as carriers of drugs, enhancers and/or converters of optical signal, immunomarkers, etc. The review examines a decade publications (2007-2016) pertaining to the various influence of nanoparticles of noble metals (gold and silver) on growth and productivity of higher plants. In fact, possible phytotoxicity of these nanoparticles is being actively studied for over 10 years. The topicality of this field of research is due to the detection of a number of natural and human-caused factors resulting in interactions of plants with nanoparticles (B.P. Colman et al., 2013; N.G. Khlebtsov et al., 2011). A positive or negative impact of nanoparticles on plants is little known, and the information is very contradictory (P. Manchikanti et al., 2010; M. Carrière et al., 2012; C. Remédios et al., 2012; N. Zuverza-Mena et al., 2016). In the study both model (Arabidopsis thaliana) and cultivated plants (soy, canola, beans, rice, radish, tomato, pumpkin, etc.) were involved. The discussed data are indicative of both positive and negative effects of metal nanoparticles on plants, as well as of the chemical nature, size, shape, surface charge, and the dose introduced being the major factors that are responsible for the processes of intracellular nanoparticle penetration. In general terms, it was mentioned that silver nanoparticles were more toxic as compared to gold ones being due to more active silver ion diffusion from the silver nanoparticle surface. Silver ions are known to inhibit effectively biosynthesis of ethylene - a phytohormone controlling processes of plant stress, aging etc., wherein gold ions do not influence ethylene biosynthesis and signaling. Considered all, metal ion toxicity exceeds considerably a toxicity of nanoparticles. The mechanism of the nanoparticle phytotoxic action is often connected with accumulation of active oxygen species in plant tissues. The use of cell suspension cultures may be a promising approach to study plant-nanoparticles interaction (E. Planchet et al., 2015). The period during which these studies are conducted is still small for elucidating all aspects with regard to biosafety. Contradictory (often conflicting) information on the impact of nanoparticles, in our opinion, is a result of diverse experimental conditions used. It is noted that while being clearly incomplete and contradictory, the obtained data suggest that a coordinated research program is needed that would detect correlations between particle parameters, experimental design, and the observed biological effects.

Keywords: gold nanoparticles, silver nanoparticles, toxicity, biological effects, plants

In recent decades, both scientists and the world community have paid much attention to nanotechnology, based on the use of objects no larger than $100 \mathrm{~nm}$ in the synthesis, assembly and modification of substances, materials and structures with unusual (often unexpected) properties. The specific characteristics (physical and chemical, structural, optical, etc.) and adequate methods of obtaining, studying and using such materials and compositions are responsible for definitions of phenomena and concepts in this dimension area [1]. Toxicological effects and the effects of metal nanoparticles and their oxides on biological systems [2] are of particular interest, since the physical and chemical characteristics of nanoparticles are signif- 
icantly different from those for larger particles and massive materials [3].

Gold and silver nanoparticles are used in a variety of biomedical practices as drug carriers, amplifiers and/or converters of the optical signal, immunomarkers, etc. [4, 5]. Thanks to the development of industrial nanotechnologies, the accidental impact of artificially created nanoparticles on plant and animal cells is becoming increasingly probable, which requires the impact analysis. According to approximate estimations, the annual production of silver nanoparticles (Ag NP) is 3-20 tons in the United States [6)], 5.5 tons in Europe [7], and global use is about 800 tons [8]. Nanoparticles may cause difficult-to-predict (including undesirable) ecological effects in the environment [9]. Gold nanoparticles (Au NP) are most actively used biomedical purposes [5], necessitating investigations of pharmacokinetics, biodistribution in organs and tissues and possible toxicity of these compounds $[10,11]$. But if a rather large number of papers have been focused on the ways of nanoparticle penetration into cell, the subsequent transformation and elimination from the cell and the organism as a whole, the toxicity of nanoparticles for microorganisms and animals [10-15], the interaction of nanoparticles with plant cells largely remains terra incognita.

There is very little evidence about the positive or negative effects of nanoparticles on plant cells and plants, and these data are highly controversial [16-20], although there are many nano-scale particles with which plants can come into contact under natural conditions. In addition, technogenic nanoparticles in their physical and chemical properties are often close to nanoparticles of natural origin. For example, recently it has been revealed that nanostructures, i.e. nanospheres and nanoplates, similar in size and shape to those produced at the laboratory are formed under the influence of climatic factors in geological deposits enriched with gold [21]. The approaches have also been reported for use of plants as a tool for biotechnological synthesis of nanoparticles ("green chemistry") [22]. It is suggested that the nanoparticle formation can serve as an anti-toxicant mechanisms in plants at metal-contaminated soils [23].

In this review, we summarized the information evolved recently on the interaction of higher plants with nanoparticles of the most widespread noble metal, such as gold and silver.

The penetration of nanoparticles into plant cells and tissues. Recently, several reviews have been published on the interaction of metallic nanoparticles with higher plants [24-27] and algae [28, 29]. It turned out that algae, especially unicellular ones, in particular Dunaliella salina Teod., are a convenient model to investigate the effects of Au NP and Ag NP on living cells [30, 31].

One of the first papers on penetration of nanoparticles into tissues and cells of plants, fungi and algae was presented by E. Navarro et al. [32]. It is known that the cell wall (a structure specific for plants, fungi and algae) limits the flow of large molecules and particles, while allowing the small ones to pass. It serves as the primary step in the interaction of a cell with nanoparticles and a barrier for their penetration. The pores which average 5-20 $\mathrm{nm}$ in diameter limit the size of nanoparticles that can pull through the cell wall. However, there is evidence that nanoparticles can themselves modulate the pore size and, removing thereby rigid structural limitations, reach the plasmalemma [32]. It is assumed that at the next stage, nanoparticles are able to enter the cell through endocytosis, but this process has not been adequately studied in plants. There is evidence that Au NPs penetrate tissues of Oryza sativa L. and Solanum lycopersicum L. due to both clathrin-dependent and clathrin-independent endocytosis [33].

To investigate the endocytosis in the growing pollen tubes of the Nicotiana tabacum L., negative and positively charged Au NPs were used [34]. Electron 
microscopy has convincingly shown that endocytosis enables the Au NPs to be rapidly captured and found in membrane vesicles. Apical growth of pollen tubes is a rather rapid process, in which the cortical actin cytoskeleton and plasmalemma are constantly changing. Perhaps in such systems (and in protoplasts), nanoparticles can be delivered to the cell through endocytosis [35]. Other types of nanoparticles, such as gold nanostars [36], paramagnetic nanoparticles [37], nanoparticles of silicon oxide [38] and magnesium oxide [39], and carbon nanotubes [40], are presumably appear in the plant tissues the same way.

A number of studies have shown [41-44] that $\mathrm{Au}$ NPs were never found in the aboveground parts of radish, pumpkin, barley, poplar, and wheat plants unlike tobacco, tomato, alfalfa, ryegrass, maize, bamboo and rice. In addition to the plant species, the efficiency of $\mathrm{Au}$ NPs penetration into the tissues depends on the size and surface charge of the nanoparticles. Positively charged Au NPs are actively absorbed only by plant roots, while negatively charged Au NPs are also able to actively move from roots to stems and leaves [33, 45]. Involvement of both plasmodesma and the vascular system of plants in this process has been under debate [41, 46]. Small nanoparticles penetrate into the aerial parts of plants more readily than large ones and, in addition, they are more toxic. For $\mathrm{Ag} \mathrm{NPs}$, this fact is probably due to a greater tendency to dissociation in small particles and the toxic action of metal ions [13, 47].

Intriguing data were obtained using mass spectrometry and X-ray fluorescence to study the intake of 5, 10 and $15 \mathrm{~nm} \mathrm{Au} \mathrm{NPs} \mathrm{in} \mathrm{N.} \mathrm{tabacum} \mathrm{tissues}$ [48]. Au NPs were found not only in the leaves but also in the tissues of tobacco hornworm (Manduca sexta), which ate them. Using artificial aquatic ecosystem as a model, it was shown [49] that gold nanorods more rapidly penetrate into the tissues of mollusks, shrimps and fish than that of aquatic plant Spartina alterniflora Loisel. At the same time, the toxicity of Ag NPs in the cells of the algae and crustaceans were detected at much lower concentrations compared to mammalian cells ( $0.1 \mathrm{mg} \mathrm{Ag} / 1$ vs $26 \mathrm{mg} \mathrm{Ag} / \mathrm{l})$ [13].

Biological effects in plants exposed to metal nanoparticles. Various toxic effects of nanoparticles on plants have been discussed in several comprehensive reviews [50-56], but data on the mechanisms of phytotoxicity reported in these publications are scarce and controversial.

S. Arora et al. [57] after studying the effect of nanoparticles on the growth and yield of mustard (Brassica juncea L.) in a field trials sprayed the plants with the Au NP suspensions of different concentration. The presence of Au NPs in the tissues was detected by atomic absorption spectroscopy. The authors reported the positive effect of $\mathrm{Au} \mathrm{NPs}$ : the length and diameter of the stem, as well as the number of leaves and shoots increased, and the yield grew. Similar results were obtained for germination of mustard seeds on growth medium [58] and with $\mathrm{Ag}$ NPs [59]. Using a synchrotron X-ray microanalysis and high-resolution transmission electron microscopy, it has been shown that Au NPs $3.5 \mathrm{~nm}$ in diameter penetrate the Nicotiana xanthi plants through the roots and move along the vascular system. The Au NP aggregates of $18 \mathrm{~nm}$ in size were detected only in the cytoplasm of the root cells [60]. Necrotic lesions of the leaves were observed 14 days after exposure to small Au NPs, but in the presence of large Au NPs, no difference vs control was observed. A lack of effect or a minor physiological effect at very high concentrations of $\mathrm{Au}$ NPs was described for Glycine max L. [61] and freshwater aquarium plants [62, 63].

When used at the early ontogenesis of Brassica napus L., Ag NPs significantly promoted the growth of roots and stems, while the energy and rate of seed germination were somewhat decreased [64]. At the same time, the treatment of Boswellia ovalifoliolata N.P. Balakr \& A.N. Henry seeds with Ag NPs 
markedly accelerated the germination and seedling growth [65]. A similar effect was observed after exposure to Ag NPs in the Asparagus officinalis L. seeds [66]. In addition, the authors noted an increase in the ascorbic acid and chlorophyll content in seedling treated with Ag NPs. A decrease in germination, a slowdown in the root nodules formation (due to a decreased number of the symbiotic bacteria Rhizobium leguminosarum) and shoot growth, and smaller root length in Vicia faba L. are described when Ag NPs were added to the culture medium [67). In hydroponic culture, the germination rate in Solanum lycopersicum [68] and Raphanus sativus L. did not decrease in the presence of Ag NPs, but root and shoot length decreased, and the photosynthetic activity was slightly reduced [69]. According to C.L. Doolette et al. [70], the potential risk of negative effects of Ag NPs on the Lactuca sativa L. plants is very low: the Ag content in the edible parts of the plant was $<1 \%$ of the total amount added to the soil. Similar findings were obtained on Lactuca sativa and Cucumis sativus L. for Ag NPs, Au NPs, and iron oxide nanoparticles [71. The authors reported low or no toxicity for all types of nanoparticles. The negative effect of the dispersion medium was sometimes more significant than that of nanoparticles, which may be due to the diffusion of metal ions into the medium. For example, after three months of storage the Ag content in nanoparticles decreased by $7 \%$ [72].

The effect of nanoparticles on the development of plants can be dosedependent. It was found [73] that when the Oryza sativa seeds were germinated on the culture medium containing Ag NPs $(30 \mathrm{mg} / \mathrm{ml})$, the root growth was enhanced, but when the concentration of nanoparticles increased to $60 \mathrm{mg} / \mathrm{ml}$, the growth of seedlings slowed down compared to the control. In addition, the number of rhizosphere microorganisms decreased due to the damage to the bacterial cell wall under the influence of $\mathrm{Ag}$ NPs. Inhibition of growth depending on the Ag NP dose and exposure was demonstrated for Lemma minor L. [74]^ signs of oxidative stress and changes in the structure of chloroplasts were observed at high concentrations. In Phaseolus radiates L. and Sorghum bicolor L. the growth inhibition due to the addition of Ag NPs was more pronounced on the culture media, but not in the soil [75]. The particle size also affects toxic effects. Thus, small $(6 \mathrm{~nm}) \mathrm{Ag}$ NPs proved to be more toxic than large ones (20$1000 \mathrm{~nm}$ ) for Spirodela polyrhiza L. [76]. It has also been shown that colloidal silver, in comparison to solid metal, inhibited the growth of Cucurbita pepo L. to a larger extent [77].

A number of the studies on the mechanisms of the nanoparticle penetration and phytotoxicity have been performed on Arabidopsis thaliana (L.) Heynh., a classical model in plant physiology [78-81].

There is evidence of the Au NPs influence on $A$. thaliana seed germination [82]. Addition of Au NPs with a diameter of $24 \mathrm{~nm} \mathrm{(10-80} \mathrm{mg/l)} \mathrm{to} \mathrm{the}$ growth media led to a 3 -fold increase in the total germination of the Arabidopsis seeds compared to control, as well as to a marked increase in the length and diameter of the stem and roots. Interesting results were presented by A.F. Taylor et al. [83]. They revealed that the root length in $A$. thaliana when grown on an agar medium containing Au NPs $(100 \mathrm{mg} / \mathrm{l})$ was reduced by $75 \%$. This was accompanied by an increase in the expression of genes that encode proteins involved in plant response to stress, i.e. glutathione transferase, glucosyltransferase, peroxidase and cytochrome P450. At the same time, the expression of genes that encode aquaporins and proteins involved in the transport of copper, cadmium, iron, and nickel ions has slightly decreased.

A much more pronounced genotoxic effect was revealed for gold chloride [84]. In general, the toxicity of metal ions significantly exceeds the toxicity of nanoparticles [85], and the phytotoxic effect of Ag NPs is higher than that of 
$\mathrm{Au}$ NPs [86]. The toxic effect was manifested in inhibition of elongation of the arabidopsis roots, an increase in the vegetation period by 2-3 days, a decrease in seed germination rate in the offspring, and, according to the authors, was due to the diffusion of silver ions from the Ag NP surface.

However, another study [87] showed that sublethal concentrations of Ag NPs (up to $1 \mathrm{mg} / \mathrm{l}$ ) had a pronounced stimulating effect on arabidopsis plants. The authors observed an increase in root length and wet weight, and the intensification of evapotranspiration in the seedlings. In this case, silver nitrate had a toxic effect even at a concentration of $0.05 \mathrm{mg} / 1$.

The effect of the shape and size of Ag NPs on the expression of phytohormone genes and the development of seedlings in arabidopsis was reported [88] and found to dose-dependent. These nanoparticles induced the expression of the auxin-dependent transcription factor gene and one of the key enzymes for the synthesis of abscisic acid. In addition, Ag NPs reduced the inhibition of root growth in the arabidopsis seedlings caused by ACC (aminocyclopropane-1carboxylic acid, the precursor of ethylene synthesis), and also reduced the expression of ACC synthesis gene (ACS7) and gene of ACC conversion to ethylene (ACO2). It was concluded that Ag NPs act at the ethylene reception stage and adversely affect its biosynthesis [88]. It is known that silver ions effectively inhibit the biosynthesis of ethylene, which is a phytohormone, regulating the processes under stressens, aging (maturation), etc., while gold ions do not affect the ethylene biosynthesis and signaling $[89,90]$. It was shown that the plasma membrane of $A$. thaliana is susceptible to Ag NPs, and when their concentration in a growth medium is $300 \mathrm{mg} / \mathrm{l}$, root elongation and leaf growth are inhibited, and the photosynthetic efficiency decreases [91]. There is a suggestion [92] that phytotoxicity is due to the accumulation of reactive oxygen species in the tissues (mainly under the influence of silver ions diffusing from Ag NP surface).

The research of the nanoparticle penetration into cells and cytotoxicity is often carried out on suspension cultures of animal and human cells [10-12, 93]. Given that the protective mechanisms against adverse factors have much in common for all living organisms, we suggest that the use of plant cell suspension cultures can be quite effective in studying the effect of metal nanoparticles on plant cells. A distinctive feature of plant cell suspension cultures is their higher susceptibility to a wide range of compounds and abiotic effects compared to the whole plant $[94,95]$. These properties are determined by the peculiarities of the physiological state of cells, including the ability to reproduce various responses at metabolic and gene regulation levels. The development of biochemical and physiological responses in the cell culture occurs over a short period and fairly evenly throughout the population (unlike entire plant or its organs). In addition, one can expect more pronounced effects of nanoparticles on cells of the suspension culture due to the absence of specialized protective structures, such as cuticle, epidermis, etc.

It has been shown that the addition of Au NPs and Ag NPs of $20 \mathrm{~nm}$ in a diameter to growth media positively influences the biomass gain in $A$. thaliana cell suspension. It has been found out that the nature of changes in $\mathrm{pH}$ of the culture media containing Au NPs and Ag NPs is not identical, since Ag NPs caused severe acidification while Au NPs alkalinized the culture medium. In the presence of metal nanoparticles, the specific respiratory activity of the $A$. thaliana cells in the suspension was insignificantly, though steadily decreased, and a decrease in the intracellular pool of free amino acids (alanine, $\gamma$-aminobutyric acid, valine) was seen, which is characteristic for responses to abiogenic stresses [96]. Moreover, the addition of nanoparticles changed the patterns of extracellular proteins and the structure of the actin cytoskeleton in the A. thaliana cell culture [97]. 
From our point of view, contradictory (often conflicting) data on the effect of gold and silver nanoparticles on plants (Table) are due to differences in design of experiments (i.e. unequal sizes and charges of nanoparticles, doses, time of observiton, etc.).

\section{The effects of noble metal nanoparticles on plants}

\begin{tabular}{|c|c|c|c|c|c|c|}
\hline \multirow{2}{*}{$\begin{array}{l}\text { Diameter, } \\
\mathrm{nm}\end{array}$} & \multicolumn{3}{|c|}{ Conditions } & \multirow{2}{*}{ Plant } & \multirow{2}{*}{ Effect } & \multirow{2}{*}{$\begin{array}{l}\text { Refer- } \\
\text { ence }\end{array}$} \\
\hline & dose & substrate & time & & & \\
\hline \multicolumn{7}{|c|}{$\mathrm{Au} \mathrm{nanoparticles}$} \\
\hline 10 & $10 \mathrm{mg} / \mathrm{l}$ & $\mathrm{H}$ & 2 weeks & Barley & $\begin{array}{l}\text { No effects on the seed germination; } \\
\text { decrease in biomass and root length }\end{array}$ & [43] \\
\hline $5,10,15$ & $30,100 \mathrm{mg} / \mathrm{l}$ & $\mathrm{H}$ & 3-7 days & Tobacco & Increased growth & [48] \\
\hline & $48 \mathrm{mg} / \mathrm{l}$ & $\mathrm{H}$ & 2 weeks & Tobacco & Necrotic lesions of leaves & [60] \\
\hline 18 & $76 \mathrm{mg} / 1$ & & & & No effects & \\
\hline $10-20$ & $0-100 \mathrm{mg} / \mathrm{kg}$ & FE & $\begin{array}{l}50-70 \\
\text { days }\end{array}$ & Mustard & $\begin{array}{l}\text { Increase in height and diameter of the } \\
\text { stem, number of leaves and shoots, yield }\end{array}$ & [57] \\
\hline 50 & $0-400 \mathrm{mg} / 1$ & $\mathrm{CM}$ & 10 days & Mustard & Increased root length & [58] \\
\hline $5,10,20$ & $0-17 \mu \mathrm{M}$ & $\mathrm{S}$ & 2 weeks & Soybean & No effects & [61] \\
\hline 24 & $10-80 \mathrm{mg} / 1$ & $\mathrm{CM}$ & 15 days & Arabidopsis & Increased total germination of seeds & [82] \\
\hline $7,18,49,108$ & $0-400 \mathrm{mg} / 1$ & $\mathrm{CM}$ & 2 weeks & Arabidopsis & Reduced root length & [83] \\
\hline 20 & $50 \mathrm{mg} / \mathrm{l}$ & $\mathrm{CM}$ & 72 hrs & Arabidopsis & $\begin{array}{l}\text { Increased biomass of the suspension } \\
\text { cell culture }\end{array}$ & {$[97]$} \\
\hline \multicolumn{7}{|c|}{ Ag nanoparticles } \\
\hline 30 & $0-400 \mathrm{mg} / \mathrm{l}$ & $\mathrm{CM}$ & 1 week & Mustard & $\begin{array}{l}\text { Increased root length, enhanced photo- } \\
\text { synthesis }\end{array}$ & {$[59]$} \\
\hline 10 & $0.75-18 \mu \mathrm{M}$ & $\mathrm{CM}$ & 1 week & Rapeseed & $\begin{array}{l}\text { Increased weight of roots and stems; } \\
\text { reduced energy and rate of seed germi- } \\
\text { nation }\end{array}$ & [64] \\
\hline $30-40$ & $10-30 \mathrm{mg} / 1$ & $\mathrm{CM}$ & 3 weeks & Boswellia & $\begin{array}{l}\text { Accelerated seed germination and } \\
\text { growth of seedlings }\end{array}$ & {$[65]$} \\
\hline 20 & $100 \mathrm{mg} / 1$ & $\mathrm{CM}$ & 25 days & Asparagus & $\begin{array}{l}\text { Increased content of ascorbic acid and } \\
\text { chlorophyll }\end{array}$ & [66] \\
\hline $5-50$ & $800 \mathrm{mg} / \mathrm{kg}$ & Soil & 5 weeks & Beans & $\begin{array}{l}\text { Reduced germination, slowing down } \\
\text { the formation of root nodules, inhibi- } \\
\text { tion of shoot growth and root length }\end{array}$ & [67] \\
\hline $10-15$ & $0-1,000 \mathrm{mg} / \mathrm{l}$ & $\mathrm{H}$ & 6 days & Tomatoes & $\begin{array}{l}\text { Significant root growth inhibition, } \\
\text { reduced photosynthesis }\end{array}$ & [68] \\
\hline 2 & $0-500 \mathrm{mg} / \mathrm{l}$ & $\mathrm{CM}$ & 5 days & Radish & $\begin{array}{l}\text { No effects on germination; decreased } \\
\text { length of roots and shoots }\end{array}$ & [69] \\
\hline 20 & $30,60 \mathrm{mg} / \mathrm{l}$ & $\mathrm{CM}$ & $1-3$ weeks & Rice & $\begin{array}{l}\text { Concentration-dependent in- } \\
\text { crease/decrease in root growth }\end{array}$ & [73] \\
\hline 10,100 & $5 \mathrm{mg} / \mathrm{l}$ & $\mathrm{CM}$ & 2 weeks & Duckweed & $\begin{array}{l}\text { Dose- and exposure-dependent inhibi- } \\
\text { tion of growth; oxidative stress, changes } \\
\text { in the chloroplast structure }\end{array}$ & [74] \\
\hline $5-25$ & $0-40 \mathrm{mg} / 1$ & $\mathrm{~S}, \mathrm{CM}$ & 5 days & $\begin{array}{l}\text { Sorghum, } \\
\text { beans }\end{array}$ & Growth inhibition & [75] \\
\hline $6,20,1000$ & $0.5-10 \mathrm{mg} / \mathrm{l}$ & $\mathrm{CM}$ & $72 \mathrm{hrs}$ & Spirodela & $\begin{array}{l}\text { Growth inhibition depending on the } \\
\text { particle size }\end{array}$ & [76] \\
\hline 100 & $0-500 \mathrm{mg} / \mathrm{l}$ & $\mathrm{H}$ & 1 week & Pumpkin & Decreased biomass & [77] \\
\hline $20-80$ & $67-535 \mathrm{mg} / 1$ & $\mathrm{H}$ & 2 weeks & Arabidopsis & $\begin{array}{l}\text { Inhibition of root elongation, vegetation } \\
\text { period is } 2-3 \text { days longer, a decrease in } \\
\text { seed germination rate in the offspring }\end{array}$ & [86] \\
\hline $5,10,25$ & $0.01-100 \mathrm{mg} /$ & & 6 weeks & Arabidopsis & $\begin{array}{l}\text { Increased length of roots, raw biomass, } \\
\text { and evapotranspiration }\end{array}$ & [87] \\
\hline 8,45 & $0-100 \mu \mathrm{M}$ & $\mathrm{CM}$ & 3 days & Arabidopsis & $\begin{array}{l}\text { Increased root length; activation of the } \\
\text { expression of genes involved in cell } \\
\text { proliferation, metabolism, and hormone } \\
\text { signaling }\end{array}$ & [88] \\
\hline 40 & $300-5,000 \mathrm{mg} /$ & $1 \mathrm{CM}$ & 4-10 days & Arabidopsis & $\begin{array}{l}\text { Inhibition of root elongation and leaf } \\
\text { growth, decreased photosynthetic effi- } \\
\text { ciency }\end{array}$ & [91] \\
\hline 100 & $50-100 \mu \mathrm{M}$ & $\mathrm{CM}$ & 10 days & Arabidopsis & Oxidative stress & [92] \\
\hline 20 & $30 \mathrm{mg} / \mathrm{l}$ & $\mathrm{CM}$ & $72 \mathrm{hrs}$ & Arabidopsis & $\begin{array}{l}\text { Increased biomass gain in suspension } \\
\text { cell culture }\end{array}$ & [97] \\
\hline
\end{tabular}

To summarize, active studies on the toxicity of nanoparticles in plants are being carried out for no more than 10 years. This period seems to be still small to clarify all the aspects of the problem as required by the biosafety principles but sufficient for some preliminary principal conclusions. The data obtained indicate both positive and negative effects of metal nanoparticles on plants [98]. Factors that undoubtedly determine the processes of intracellular penetration of 
nanoparticles are their chemical nature, size, shape, surface charge, and dose. The available methods for the determination of metals in organs, the localization and identification of nanoparticles at the cellular and subcellular levels, as well as for in vitro estimation of cytotoxicity are relevant, and has been robustly tested. The cell suspension cultures may serve a promising tool for studying the effect of metal nanoparticles on plants.

Therefore, the problem of metal nanoparticles-plants interaction, despite the urgency, is far from a convincing solution. We need a coordinated research program that would reveal the correlations between the parameters of the particles (size, shape, surface functionalisation), the design of experiments (model, dose, method and timing, duration of observations, studied organs, cells, subcellular structures, etc.) and the observed biological effects, including these in trophic chains. In addition, concerted efforts are required to introduce standards for particles and methods used to test the toxicity of nanomaterials

\section{REFEREN CES}

1. Shchyogolev S.Y. On nanotechnologies in biological research and on the role of biological knowledge in their development. In: Gold nanoparticles: properties, characterization and fabrication. P.E. Chow (ed.). Nova Sci. Publ., NY, 2010: 277-285.

2. Schwab F., Zhai G., Kern M., Turner A., Schnoor J.L., Wiesner M.R. Barriers, pathways and processes for uptake, translocation and accumulation of nanomaterials in plants - Critical review. Nanotoxicology, 2016, 10: 257-278 (doi: 10.3109/17435390.2015.1048326).

3. Sengupta J., Ghosh S., D a t a P., Gomes A. Physiologically important metal nanoparticles and their toxicity. J. Nanosci. Nanotechnol., 2014, 14: 990-1006 (doi: 10.1166/jnn.2014.9078).

4. Dreaden E.C., Alkilany A.M., Huang X., Murphy C.J., E1-Sayed M.A. The golden age: gold nanoparticles for biomedicine. Chem. Soc. Rev., 2012, 41: 2740-2779 (doi: $10.1039 / \mathrm{c} 1 \mathrm{cs} 15237 \mathrm{~h})$.

5. Dykman L.A., Khlebts o v N.G. Gold nanoparticles in biomedical applications: recent advances and perspectives. Chem. Soc. Rev., 2012, 41: 2256-2282 (doi: 10.1039/C1CS15166E).

6. Hendren C.O., Mesnard X., Dröge J., Wiesner M.R. Estimating production data for five engineered nanomaterials as a basis for exposure assessment. Environ. Sci. Technol., 2011, 45: 2562-2569 (doi: 10.1021/es103300g).

7. Piccinno F., Gottschalk F., Seeger S., Nowack B. Industrial production quantities and uses of ten engineered nanomaterials in Europe and the world. J. Nanopart. Res., 2012, 14: 1109 (doi: 10.1007/s11051-012-1109-9).

8. Geisler-Lee J., Brooks M., Gerfen J.R., Wang Q., Fotis C., Sparer A., Ma X., Berg R.H., Geisler M. Reproductive toxicity and life history study of silver nanoparticle effect, uptake and transport in Arabidopsis thaliana. Nanomaterials, 2014, 4: 301-318 (doi: 10.3390/nano4020301).

9. Colman B.P., Arnaout C.L., Anciaux S., Gunsch C.K., Hochella M.F., Jr., Kim B., Lowry G.V., McGill B.M., Reinsch B.C., Richardson C.J., Unrine J.M., Wright J.P., Yin L., Bernhardt M.S. Low concentrations of silver nanoparticles in biosolids cause adverse ecosystem responses under realistic field scenario. PLOS ONE, 2013, 8: e57189 (doi: 10.1371/journal.pone.0057189).

10. Alkilany A., Murphy C. Toxicity and cellular uptake of gold nanoparticles: what we have learned so far? J. Nanopart. Res., 2010, 12: 2313-2333 (doi: 10.1007/s11051-010-9911-8).

11. Khlebtsov N.G., Dykman L.A. Biodistribution and toxicity of engineered gold nanoparticles: A review of in vitro and in vivo studies. Chem. Soc. Rev., 2011, 40: 1647-1671 (doi: $10.1039 / \mathrm{c} 0 \mathrm{cs} 00018 \mathrm{c}$ ).

12. Lewinski N., Colvin V., Drezek R. Cytotoxicity of nanoparticles. Small, 2008, 4: 26-49 (doi: 10.1002/smll.200700595).

13. Ivask A., Kurvet I., Kasemets K., Blinova I., Aruoja V., Suppi S., Vija H., Käkinen A., Titma T., Heinlaan M., Visnapuu M., Koller D., Kisand V., Kahru A. Size-dependent toxicity of silver nanoparticles to bacteria, yeast, algae, crustaceans and mammalian cells in vitro. PLoS ONE, 2014, 9: e102108 (doi: 10.1371/journal.pone.0102108).

14. Azhdarzadeh M., Saei A.A., Sharifi S., Hajipour M.J., Alkilany A.M., Sharifzadeh M., Ramazani F., Laurent S., Mashaghi A., Mahmoudi M. Nanotoxicology: advances and pitfalls in research methodology. Nanomedicine (Lond.), 2015, 10: 2931-2952 (doi: $10.2217 / \mathrm{nnm} .15 .130)$.

15. Carne i ro M.F.H., B a rbos a F., Jr. Gold nanoparticles: A critical review of therapeutic applications and toxicological aspects. J. Tox. Environ. Health B, 2016, 19: 129-148 (doi: 
10.1080/10937404.2016.1168762).

16. Manchikanti P., Bandopadhyay T.K. Nanomaterials and effects on biological systems: development of effective regulatory norms. Nanoethics, 2010, 4: 77-83 (doi: 10.1007/s11569010-0084-9).

17. Carrière M., La rue C. Toxicology: plants and nanoparticles. In: Encyclopedia of nanotechnology. B. Bhushan (ed.). Springer, NY, 2012: 2763-2767.

18. M a s a rovičová E., K rál'ová K. Metal nanoparticles and plants. Ecol. Chem. Eng. S, 2013, 20: 9-22 (doi: 10.2478/eces-2013-0001).

19. Remédios C., Rosário F., Bastos V. Environmental nanoparticles interactions with plants: morphological, physiological, and genotoxic aspects. J. Botany, 2012, 2012: Article ID 751686 (doi: 10.1155/2012/751686).

20. Nanotechnology and plant sciences. Nanoparticles and their impact on plants. M.H. Siddiqui, M.H. Al-Whaibi, F. Mohammad (eds.). Springer, NY, 2015 (doi: 10.1007/978-3-319-14502-0).

21. Hough R.M., Noble R.R.P., Hitchen G.J., Hart R., Reddy S.M., Saunders M., Clode P., Vaughan D., Lowe J., Gray D.J., Anand R.R., Butt C.R.M., Verrall M. Naturally occurring gold nanoparticles and nanoplates. Geology, 2008, 36: 571-574 (doi: 10.1130/G24749A.1).

22. Iravani S. Green synthesis of metal nanoparticles using plants. Green Chem., 2011, 13: 2638-2650 (doi: 10.1039/C1GC15386B).

23. Shukla D., Krishnamurthy S., Sahi S.V. Microarray analysis of Arabidopsis under gold exposure to identify putative genes involved in the synthesis of gold nanoparticles (AuNPs). Genom. Data, 2015, 3: 100-102 (doi: 10.1016/j.gdata.2014.12.001).

24. Eggenberger K., Frey N., Zienicke B., Siebenbrock J., Schunck T., Fischer R., Bräse S., Birtalan E., Nann T., Nick P. Use of nanoparticles to study and manipulate plant cells. Adv. Eng. Mat., 2010, 12: B406-B412.

25. Bhatt I., Tripathi B.N. Interaction of engineered nanoparticles with various components of the environment and possible strategies for their risk assessment. Chemosphere, 2011, 82: 308317 (doi: 10.1016/j.chemosphere.2010.10.011).

26. Thul S.T., Sarangi B.K., Pandey R.A. Nanotechnology in agroecosystem: implications on plant productivity and its soil environment. Expert Opin. Environ. Biol., 2013, 2: 1 (doi: 10.4172/2325-9655.1000101).

27. Thwala M., Klaine S.J., Musee N. Interactions of metal-based engineered nanoparticles with aquatic higher plants: A review of the state of current knowledge. Environ. Toxicol. Chem., 2016, 35: 1677-1694 (doi: 10.1002/etc.3364)

28. Quigg A., Chin W.-C., Chen C.-S., Zhang S., Jiang Y., Miao A.-J., Schwehr K.A., Xu C., S a n ts chi P.H. Direct and indirect toxic effects of engineered nanoparticles on algae: role of natural organic matter. ACS Sustainable Chem. Eng., 2013, 1: 686-702 (doi: 10.1021/sc400103x).

29. Moreno-Garrido I., Pérez S., Blasco J. Toxicity of silver and gold nanoparticles on marine microalgae. Mar. Environ. Res., 2015, 111: 60-73 (doi: 10.1016/j.marenvres.2015.05.008).

30. Bogatyrev V.A., Golubev A.A., Selivanov N.Yu., Prilepskii A.Yu., Bukina O.G., Pylaev T.E., Bibikova O.A., Dykman L.A., Khlebtsov N.G. Rossiiskie nanotekhnologii, 2015, 10: 92-99 (in Russ.).

31. Golubev A.A., Prilepskii A.Y., Dykman L.A., Khlebtsov N.G., Bogatyrev V.A. Colorimetric evaluation of the viability of the microalga Dunaliella salina as a test tool for nanomaterial toxicity. Tox. Sci., 2016, 151: 115-125 (doi: 10.1093/toxsci/kfw023).

32. Navarro E., Baun A., Behra R., Hartmann N.B., Filser J., Miao A.-J., Quigg A., Santschi P.H., Sigg L. Environmental behavior and ecotoxicity of engineered nanoparticles to algae, plants, and fungi. Ecotoxicology, 2008, 17: 372-386 (doi: 10.1007/s10646-008-0214-0).

33. Li H., Ye X., Guo X., Geng Z., Wang G. Effects of surface ligands on the uptake and transport of gold nanoparticles in rice and tomato. J. Hazard. Mater., 2016, 314: 188-196 (doi: 10.1016/j.jhazmat.2016.04.043).

34. Moscatelli A., Ciampolini F., Rodighiero S., Onelli E., Cresti M., Santo N., Idilli A. Distinct endocytic pathways identified in tobacco pollen tubes using charged nanogold. J. Cell Sci., 2007, 120: 3804-3819 (doi: 10.1242/jcs.012138).

35. Onelli E., Prescianotto-Baschong C., Caccianiga M., Moscatelli A. Clathrindependent and independent endocytic pathways in tobacco protoplasts revealed by labelling with charged nanogold. J. Exp. Bot., 2008, 59: 3051-3068 (doi: 10.1093/jxb/ern154).

36. Su Y.H., Tu S.-L., Tseng S.-W., Chang Y.-C., Chang S.-H., Zhang W.-M. Influence of surface plasmon resonance on the emission intermittency of photoluminescence from gold nano-sea-urchins. Nanoscale, 2010, 2: 2639-2646 (doi: 10.1039/c0nr00330a).

37. González-Melendi P., Fernández-Pacheco R., Coronado M.J., Corredor E., Testillano P.S., Risueco M.C., Marquina C., Ibarra M.R., Rubiales D., Pérezde-Luque A. Nanoparticles as smart treatment-delivery systems in plants: assessment of different techniques of microscopy for their visualization in plant tissues. Ann. Bot., 2008, 101: 187-195 (doi: 10.1093/aob/mcm283). 
38. Torney F., Trewy n B.G., Li n V.S.-Y., Wa ng K. Mesoporous silica nanoparticles deliver DNA and chemicals into plants. Nat. Nanotechnol., 2007, 2: 295-300 (doi: 10.1038/nnano.2007.108).

39. Wang W.-N., Tarafdar J.C., Biswas P. Nanoparticle synthesis and delivery by an aerosol route for watermelon plant foliar uptake. J. Nanopart. Res., 2013, 15: 1417 (doi: 10.1007/s11051013-1417-8).

40. Khodakovskaya M., Dervishi E., Mahmood M., Xu Y., Li Z., Watanabe F., Biris A.S. Carbon nanotubes are able to penetrate plant seed coat and dramatically affect seed germination and plant growth. ACS Nano, 2009, 3: 3221-3227 (doi: 10.1021/nn900887m).

41. Koelmel J., Leland T., Wang H., Amarasiriwardena D., Xing B. Investigation of gold nanoparticles uptake and their tissue level distribution in rice plants by laser ablation-inductively coupled-mass spectrometry. Environ. Pollut., 2013, 174: 222-228 (doi: 10.1016/j.envpol.2012.11.026).

42. Judy J.D., Unrine J.M., Rao W., Wirick S., Bertsch A.M. Bioavailability of gold nanomaterials to plants: importance of particle size and surface coating. Environ. Sci. Technol., 2012, 46: 8467-8474 (doi: 10.1021/es3019397).

43. Feichtmeier N.S., Walther P., Leopold K. Uptake, effects, and regeneration of barley plants exposed to gold nanoparticles. Environ. Sci. Pollut. Res. Int., 2015, 22: 8549-8558 (doi: 10.1007/s11356-014-4015-0).

44. Hwang B.G., Ahn S., Lee S.J. Use of gold nanoparticles to detect water uptake in vascular plants. PLoS ONE, 2014, 9: e114902 (doi: 10.1371/journal.pone.0114902).

45. Zhu Z.-J., Wang H., Yan B., Zheng H., Jiang Y., Miranda O.R., Rotello V.M., Xing B., Vachet R.W. Effect of surface charge on the uptake and distribution of gold nanoparticles in four plant species. Environ. Sci. Technol., 2012, 46: 12391-12398 (doi: $10.1021 / \mathrm{es} 301977 \mathrm{w})$.

46. Zhai G., Walters K.S., Peate D.W., Alvarez P.J., Schnoor J.L. Transport of gold nanoparticles through plasmodesmata and precipitation of gold ions in woody poplar. Environ. Sci. Technol. Lett., 2014, 1: 146-151 (doi: 10.1021/ez400202b).

47. Boenigk J., Beisser D., Zimmermann S., Bock C., Jakobi J., Grabner D., Großmann L., Rahmann S., Barcikowski S., Sures B. Effects of silver nitrate and silver nanoparticles on a planktonic community: general trends after short-term exposure. PLoS ONE, 2014, 9: e95340 (doi: 10.1371/journal.pone.0095340).

48. J u d y J.D., Un ri n e J.M., B e r t s ch A.M. Evidence for biomagnification of gold nanoparticles within a terrestrial food chain. Environ. Sci. Technol., 2011, 45: 776-781 (doi: 10.1021/es103031a).

49. Ferry J.L., Craig P., Hexel C., Sisco P., Frey R., Pennington P.L., Fulton M.H., Scott G., Decho A.W., Kashiwada S., Murphy C.J., Shaw T.J. Transfer of gold nanoparticles from the water column to the estuarine food web. Nat. Nanotechnol., 2009, 4: 441-444 (doi: 10.1038/nnano.2009.157).

50. Ma X., Geiser-Lee J., Deng Y., Kolmakov A. Interactions between engineered nanoparticles (ENPs) and plants: Phytotoxicity, uptake and accumulation. Sci. Total Environ., 2010, 408: 3053-3061 (doi: 10.1016/j.scitotenv.2010.03.031).

51. Dietz K.J., Herth S. Plant nanotoxicology. Trends Plant Sci., 2011, 16: 582-589 (doi: 10.1016/j.tplants.2011.08.003).

52. Rico C.M., Majumdar S., Duarte-Gardea M., Peralta-Videa J.R., GardeaTorresdey J.L. Interaction of nanoparticles with edible plants and their possible implications in the food chain. J. Agric. Food Chem., 2011, 59: 3485-3498 (doi: 10.1021/jf104517j).

53. Wilson-Corral V., Anderson C.W., Rodriguez-Lopez M. Gold phytomining. A review of the relevance of this technology to mineral extraction in the 21st century. J. Environ. Manage., 2012, 111: 249-257 (doi: 10.1016/j.jenvman.2012.07.037).

54. Aslani F., Bagheri S., Muhd Julkapli N., Juraimi A.S., Hashemi F.S., Baghdadi A. Effects of engineered nanomaterials on plants growth: An overview. Sci. World J., 2014, 2014: Article ID 641759 (doi: 10.1155/2014/641759).

55. Arruda S.C., Silva A.L., Galazzi R.M., Azevedo R.A., Arruda M.A. Nanoparticles applied to plant science: A review. Talanta, 2015, 131: 693-705 (doi: 10.1016/j.talanta.2014.08.050).

56. Chichiricct G., Poma A. Penetration and toxicity of nanomaterials in higher plants Nanomaterials, 2015, 5: 851-873 (doi: 10.3390/nano5020851).

57. Arora S., Sharma P., Kumar S., Nayan R., Khanna P.K., Zaidi M.G.H. Goldnanoparticle induced enhancement in growth and seed yield of Brassica juncea. Plant Growth Regul., 2012, 66: 303-310 (doi: 10.1007/s10725-011-9649-z).

58. Gunjan B., Zaidi M.G.H., Sandeep A. Impact of gold nanoparticles on physiological and biochemical characteristics of Brassica juncea. J. Plant Biochem. Physiol., 2014, 2: 133 (doi: 10.4172/2329-9029.1000133).

59. Sharma P., Bhatt D., Zaidi M.G.H., Saradhi P.P., Khanna P.K., Arora S. Silver nanoparticle-mediated enhancement in growth and antioxidant status of Brassica juncea. Appl. Biochem. Biotechnol., 2012, 167: 2225-2233 (doi: 10.1007/s12010-012-9759-8).

60. Sabo-Attwood T., Unrine J.M., Stone J.W., Murphy C.J., Ghoshroy S., Blom D., Bertsch P.M., New man L.A. Uptake, distribution and toxicity of gold nanoparticles in tobacco 
(Nicotiana xanthi) seedlings. Nanotoxicology, 2012, 6: 353-360 (doi: 10.3109/17435390.2011.579631).

61. Falco W.F., Botero E.R., Falcão E.A., Santiago E.F., Bagnato V.S., Caires A.R.L. In vivo observation of chlorophyll fluorescence quenching induced by gold nanoparticles. $J$. Photochem. Photobiol. A, 2011, 225: 65-71 (doi: 10.1016/j.jphotochem.2011.09.027).

62. Glenn J.B., White S.A., Klaine S.J. Interactions of gold nanoparticles with freshwater aquatic macrophytes are size and species dependent. Environ. Toxicol. Chem., 2012, 31: 194-201 (doi: 10.1002/etc.728).

63. Ostroumov S.A., Poklonov V.A., Kot elevtsev S.V., Orlov S.N. Vestnik Moskovskogo universiteta. Seriya 16. Biologiya, 2014, 3: 19-23 (in Russ.).

64. Gusev A.A., Aki mova O.A., Krutyakov Yu.A., K li mov A.I., Denisov A.N., Kuznetsov D.V., Gody m chuk A.Yu., I khalaine n E.S. Naukovedenie, 2013, 5: 11TVN513. Available http://naukovedenie.ru/PDF/11tvn513.pdf. Accessed January 30, 2017 (in Russ.).

65. Savithramma N., Ankanna S., Bhumi G. Effect of nanoparticles on seed germination and seedling growth of Boswellia ovalifoliolata - an endemic and endangered medicinal tree taxon. Nano Vision, 2012, 2: 61-68.

66. An J., Zhang M., Wang S., Tang J. Physical, chemical and microbiological changes in stored green asparagus spears as affected by coating of silver nanoparticles-PVP. LWT Food Sci. Technol., 2008, 41: 1100-1107 (doi: 10.1016/j.lwt.2007.06.019).

67. Abd-Alla M.H., Nafady N.A., Khalaf D.M. Assessment of silver nanoparticles contamination on faba bean-Rhizobium leguminosarum bv. viciae-Glomus aggregatum symbiosis: Implications for induction of autophagy process in root nodule. Agric. Ecosyst. Environ., 2016, 218: 163-177 (doi: 10.1016/j.agee.2015.11.022).

68. S o ng U., Ju n H., Wa ld ma n B., R o h J., K i m Y., Y i J., L e e E.J. Functional analyses of nanoparticle toxicity: A comparative study of the effects of $\mathrm{TiO} 2$ and $\mathrm{Ag}$ on tomatoes (Lycopersicon esculentum). Ecotoxicol. Environ. Saf., 2013, 93: 60-67 (doi: 10.1016/j.ecoenv.2013.03.033).

69. Zuverza-Mena N., Armendariz R., Peralta-Videa J.R., Gardea-Torresdey J.L. Effects of silver nanoparticles on radish sprouts: root growth reduction and modifications in the nutritional value. Front. Plant Sci., 2016, 7: 90 (doi: 10.3389/fpls.2016.00090).

70. Doolette C.L., McLaughlin M.J., Kirby J.K., Navarro D.A. Bioavailability of silver and silver sulfide nanoparticles to lettuce (Lactuca sativa): Effect of agricultural amendments on plant uptake. J. Hazard. Mater., 2015, 300: $788-795$ (doi: 10.1016/j.jhazmat.2015.08.012).

71. Barrena R., Casals E., Colun J., Font X., Sánchez A., Puntes V. Evaluation of the ecotoxicity of model nanoparticles. Chemosphere, 2009, 75: 850-857 (doi: 10.1016/j.chemosphere.2009.01.078).

72. Galazzi R.M., de Barros Santos E., Caurin T., de Souza Pessôa G., Mazali I.O., Arruda M.A.Z. The importance of evaluating the real metal concentration in nanoparticles post-synthesis for their applications: A case-study using silver nanoparticles. Talanta, 2016, 146: 795-800 (doi: 10.1016/j.talanta.2015.06.016).

73. Mirzajani F., Askari H., Hamzelou S., Farzaneh M., Ghassempour A. Effect of silver nanoparticles on Oryza sativa L. and its rhizosphere bacteria. Ecotoxicol. Environ. Saf., 2013, 88: 48-54 (doi: 10.1016/j.ecoenv.2012.10.018).

74. Gubbins E.J., Batty L.C., Lead J.R. Phytotoxicity of silver nanoparticles to Lemna minor L. Environ. Pollut., 2011, 59: 1551-1559 (doi: 10.1016/j.envpol.2011.03.002).

75. Lee W.M., Kwak J.I., An Y.J. Effect of silver nanoparticles in crop plants Phaseolus radiatus and Sorghum bicolor: Media effect on phytotoxicity. Chemosphere, 2012, 86: 491-499 (doi: 10.1016/j.chemosphere.2011.10.013).

76. Jiang H.S., Qiu X.N., Li G.B., Li W., Yin L.Y. Silver nanoparticles induced accumulation of reactive oxygen species and alteration of antioxidant systems in the aquatic plant Spirodela polyrhiza. Environ. Toxicol. Chem., 2014, 33: 1398-1405 (doi: 10.1002/etc.2577).

77. Musante C., White J.C. Toxicity of silver and copper to Cucurbita pepo: differential effects of nano and bulk-size particles. Environ. Toxicol., 2012, 27: 510-517 (doi: 10.1002/tox.20667).

78. Taylor A. Gold uptake and tolerance in Arabidopsis. PhD Thesis. University of York, York (UK), 2011. Available http://etheses.whiterose.ac.uk/2002/. Accessed January 30, 2017.

79. Kaveh R., Li Y.-S., Ranjbar S., Tehrani R., Brueck C.L., Van Aken B. Changes in Arabidopsis thaliana gene expression in response to silver nanoparticles and silver ions. Environ. Sci. Technol., 2013, 47: 10637-10644 (doi: 10.1021/es402209w).

80. Koo Y., Lukianova-Hleb E.Y., Pan J., Thompson S.M., Lapotko D.O., Braam J. In planta response of Arabidopsis to photothermal impact mediated by gold nanoparticles. Small, 2016, 12: 623-630 (doi: 10.1002/smll.201502461).

81. Bao D., Oh Z.G., Chen Z. Characterization of silver nanoparticles internalized by Arabidopsis plants using single particle ICP-MS analysis. Front. Plant Sci., 2016, 7: 32 (doi: 10.3389/fpls.2016.00032).

82. Kumar V., Guleria P., Kumar V., Yadav S.K. Gold nanoparticle exposure induces growth and yield enhancement in Arabidopsis thaliana. Sci. Total Environ., 2013, 461-462: 462468 (doi: 10.1016/j.scitotenv.2013.05.018). 
83. Taylor A.F., Rylott E.L., Anderson C.W.N., Bruce N.C. Investigating the toxicity, uptake, nanoparticle formation and genetic response of plants to gold. PLoS ONE, 2014, 9: e93793 (doi: 10.1371/journal.pone.0093793).

84. Shukla D., Krishnamurthy S., Sahi S.V. Genome wide transcriptome analysis reveals ABA mediated response in Arabidopsis during gold (AuCl4-) treatment. Front. Plant Sci., 2014, 5: 652 (doi: 10.3389/fpls.2014.00652).

85. Notter D.A., Mitrano D.M., Nowack B. Are nanosized or dissolved metals more toxic in the environment? A meta-analysis. Environ. Toxicol. Chem., 2014, 33: 2733-2739 (doi: 10.1002/etc.2732).

86. Geisler-Lee J., Wang Q., Yao Y., Zhang W., Geisler M., Li K., Huang Y., Chen Y., Kolmakov A., Ma X. Phytotoxicity, accumulation and transport of silver nanoparticles by Arabidopsis thaliana. Nanotoxicology, 2013, 7: 323-337 (doi: 10.3109/17435390.2012.658094).

87. Wang J., Koo Y., Alexander A., Yang Y., Westerhof S., Zhang Q., Schnoor J.L., Colvin V.L., Braam J., Alvarez P.J.J. Phytostimulation of poplars and Arabidopsis exposed to silver nanoparticles and Ag+ at sublethal concentrations. Environ. Sci. Technol., 2013, 47: 5442-5449 (doi: 10.1021/es4004334).

88. Syu Y.-Y., Hung J.-H., C hen J.-C., Chuang H.-W. Impacts of size and shape of silver nanoparticles on Arabidopsis plant growth and gene expression. Plant Physiol. Biochem., 2014, 83: 57-64.

89. $\mathrm{Ku}$ ma r V., Parvat a $\mathrm{m}$ G., R a vis hank a r G.A. AgNO3 - a potential regulator of ethylene activity and plant growth modulator. Electron. J. Biotechnol., 2009, 12(2): 1 (doi: 10.2225/vol12-issue2-fulltext-1).

90. B ind e r B.M., Rodriguez F.I., Bleecker A.B., Patterson S.E. The effects of Group 11 transition metals, including gold, on ethylene binding to the ETR1 receptor and growth of Arabidopsis thaliana. FEBS Lett., 2007, 581: 5105-5109 (doi: 10.1016/j.febslet.2007.09.057).

91. Sosan A., Svistunenko D., Straltsova D., Tsiurkina K., Smolich I., Lawson T., Subramaniam S., Golovko V., Anderson D., Sokolik A., Colbeck I., Demidchik V. Engineered silver nanoparticles are sensed at the plasma membrane and dramatically modify the physiology of Arabidopsis thaliana plants. Plant J., 2016, 85: 245-257 (doi: 10.1111/tpj.13105).

92. Wen Y., Zhang L., Chen Z., Sheng X., Qiu J., Xu D. Co-exposure of silver nanoparticles and chiral herbicide imazethapyr to Arabidopsis thaliana: Enantioselective effects. Chemosphere, 2016, 145: 207-214 (doi: 10.1016/j.chemosphere.2015.11.035).

93. Dykman L.A., Khlebtsov N.G. Uptake of engineered gold nanoparticles into mammalian cells. Chem. Rev., 2014, 114: 1258-1288 (doi: 10.1021/cr300441a).

94. Rains D.W. Plant tissue and protoplast culture: applications to stress physiology and biochemistry. In: Plants under stress. H.G. Jones, T.J. Flowers, M.B. Jones (eds.). Cambridge University Press, Cambridge, 2008: 181-196.

95. Santos A.R., Miguel A.S., Tomaz L., Malhu R., Maycock C., Vaz Patto M.C., Fevereiro P., Oliva A. The impact of CdSe/ZnS Quantum Dots in cells of Medicago sativa in suspension culture. J. Nanobiotechnol., 2010, 8: 24 (doi: 10.1186/1477-3155-8-24).

96. Planchet E., Limami A.M. Amino acid synthesis under abiotic stress. In: Amino acids in higher plants. J.P.F. D’Mello (ed.). CAB Int., Wallingford, 2015: 262-276.

97. Selivanov N.Y., Selivanova O.G., Sokolov O.I., Sokolova M.K., Sokolov A.O., Bogatyrev V.A., Dykman L.A. Effect of gold and silver nanoparticles on the growth of the Arabidopsis thaliana cell suspension culture. Nanotechnologies in Russia, 2017, 12: 116-124 (doi: 10.1134/S1995078017010104).

98. Zuverza-Mena N., Martínez-Fernández D., Du W., Hernandez-Viezcas J.A., Bonilla-Bird N., López-Moreno M.L., Komárek M., Peralta-Videa J.R., Gardea-Torresdey J.L. Exposure of engineered nanomaterials to plants: Insights into the physiological and biochemical responses - A review. Plant Physiol. Biochem., 2017, 110: 236-264 (doi: 10.1016/j.plaphy.2016.05.037). 